\title{
The winged figure in the "Villa dei Misteri" fresco and the spinning top in ancient rituals
}

\section{Marianna Scapini}

\section{(e) OpenEdition \\ 1 Journals}

\section{Electronic version}

URL: http://journals.openedition.org/mythos/509

DOI: $10.4000 /$ mythos.509

ISSN: 2037-7746

\section{Publisher}

Salvatore Sciascia Editore

\section{Printed version}

Date of publication: 1 December 2016

Number of pages: 193-213

ISBN: 978-88-8241-476-4

ISSN: $1972-2516$

\section{Electronic reference}

Marianna Scapini, «The winged figure in the "Villa dei Misteri" fresco and the spinning top in ancient rituals », Mythos [Online], 10 | 2016, Online since 24 September 2019, connection on 28 September 2019. URL : http://journals.openedition.org/mythos/509; DOI : 10.4000/mythos.509 


\section{The winged figure in the "Villa dei Misteri" fresco and the spinning top in ancient rituals}

\section{Marianna Scapini}

\begin{abstract}
This paper focuses on the megalography of the "Villa dei Misteri" and its winged figure provided with a scourge. A few literary sources suggest a new interpretation of her action. In particular, I believe that this character hints at a whipping actually echoed in Dionysiac rituals. This whipping was aimed at prompting the acolyte to a whirling dance step. This choreography was based upon the parallelism between the dancer and a spinning top, traditionally put in motion by

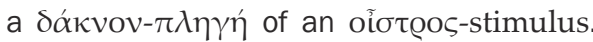
The infernal shape of the figure evokes the Furies of luno, who commonly bear stimuli to produce a Dionysiac mania. The presence of a Dionysiac "spinning top dance" is also consistent with the hierogamic theme central in the fresco, since the spinning top was also connected to the female initiations (which in my opinion are evoked in the megalography) and to the symbolism of love, marriage and, more generally, of life - through the parallelism with the spindle, too.
\end{abstract}

\section{Keywords}

"Villa dei Misteri" • Dionysiac rituals • Whipping • Spinning top • Ritual dances

Parole chiave

Villa dei Misteri - Riti dionisiaci - Frustate - Trottola • Danze rituali

\section{Riassunto}

Lo studio riesamina la megalografia della Villa dei Misteri ed in particolare la figura alata munita di frusta che vi spicca. Indizi presenti nelle fonti letterarie suggeriscono una nuova interpretazione del gesto compiuto dal personaggio. Si parte dall'ipotesi che questo alluda ad una fustigazione realmente evocata in alcuni riti dionisiaci. Le frustate sarebbero state finalizzate ad indurre il partecipante al rito ad un passo di danza circolare. La coreografia sarebbe stata basata sul parallelismo tra il danzatore (o la danzatrice) ed una trottola, oggetto tradizionalmente messo in moto dal סókvov-

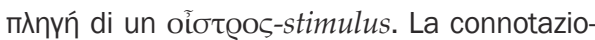
ne infernale del personaggio evoca le Furie di Giunone, che erano spesso rappresentate munite di stimuli con i quali scatenavano nelle loro vittime una mania di carattere dionisiaco. La presenza di una "danza della trottola" dionisiaca è coerente con il tema ierogamico che è centrale nell'affresco, dal momento che la trottola era connessa anche alle iniziazioni femminili (che a mio avviso sono evocate nel fregio) e al simbolismo dell'amore, del matrimonio e, più in generale, della vita - anche attraverso il parallelismo dell'oggetto con il fuso tessile.

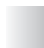


The interpretation of the scene with the winged figure has followed two main streams. The first hypothesis claims that it represents a whipping and that the character is connected to the kneeling woman depicted in the adjacent wall. This idea was followed firstly by De Petra ${ }^{1}$ and later mainly by Toynbee ${ }^{2}$, Bieber $^{3}$, Macchioro $^{4}$, Maiuri $^{5}$, Picard ${ }^{6}$, Simon $^{7}$, Schefold ${ }^{8}$, Zuntz ${ }^{9}$, Boyancé ${ }^{10}$, Brendel ${ }^{11}$, Marsoner ${ }^{12}$, Grieco ${ }^{13}$ and Merkelbach ${ }^{14}$. The second interpretation excludes the whipping of the kneeling girl. It was strongly supported by Rizzo ${ }^{15}$ and then by Comparetti ${ }^{16}$, Rostovtzeff ${ }^{17}$, Bendinelli ${ }^{18}$, Nilsson ${ }^{19}$, Turcan ${ }^{20}$, Ricciardelli $^{21}$, Guarducci ${ }^{22}$ and Veyne ${ }^{23}$.

In order to support the hypothesis of the whipping, De Petra ${ }^{24}$ quotes a passage by Pausanias concerning a whipping ritual involving women in the temple of Dionysus in Alea ${ }^{25}$. Macchioro also recalls the thyrsopleges, "beaten by the thyrsus", in the Bacchic ceremonies, mentioned by Hesychius ${ }^{26}$, and mentions the Roman rite of the Lupercalia - when the Lu-

1 De Petra 1910.

2 TOYNBEE 1929.

3 Bieber 1928.

4 MaCCHIORO 1929.

5 Maiuri 1931.

6 PiCARD 1954.

7 SimON 1961.

8 SChefold 1952.

9 ZunTz 1963.

10 BOYANCÉ 1966 and BoYANCÉ I 966².

11 Brendel 1966 and Brendel 1980.

12 Marsoner 1989/1990.

13 Grieco 1979.

14 Merkelbach 2003.

15 Rizzo 1918.

16 Comparetti 1921.

17 Rostovtzeff 1928.

18 Bendinelli 1936 and Bendinelli 1968.

19 Nilsson 1957.

20 Turcan 1969 and Turcan 1982.

21 RicCIARDELLI 2000.

22 GuarducCi 1993.

23 In Veyne, Lissarrague, Frontisi-Ducroux 2003. For a more general and complete bibliography regarding the fresco see my recent published book: SCAPINi 2016a, 185-231.

24 De Petra 1910.

25 In honour of Dionysus they celebrate every other year a festival called Sciereia, and at this festival, in obedience to a response from Delphi, women are flogged ( $\mu \alpha \sigma \tau \mathrm{l} \gamma \mathrm{O} \tilde{v} \tau \alpha \mathrm{L})$, just as the Spartan lads are flogged at the image of the Orthian goddess: Paus. VIII, 23: transl. by W.H.S. Jones and H.A. Ormerod.


ORO 1929, 137-8) another proof of the ritual of whipping in Greek Dionysism is offered by a scholiast of Aristophanes (Schol. Aristoph. Ran. 501). Regarding the epithet mastighias given to Heracles in the Ranae, the scholiast connects it to a tradition concerning an initiation of Heracles into the "Lesser Mysteries of Melite":

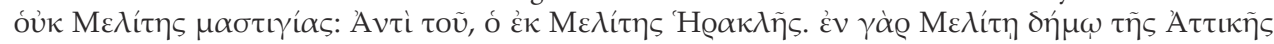

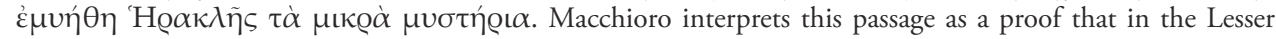
Mysteries of Agrae, where Eleusinian religion mingled with Dionysism, a whipping ceremony was performed. 
perci whipped the women - and the whipping rituals during certain ceremonies in honour of Demeter, that Hesychius also recalled ${ }^{27}$. Maiuri provides, too, the example of Alea and the Lupercalia, saying that the ritual shown in Pompeii was actually performed in order to propitiate female fertility. This position was basically followed by Picard ${ }^{28}$ and Erika Simon ${ }^{29}$. Jocelyn Toynbee and Margarete Bieber, in their turn, have opened the way to a nuptial interpretation of the fresco ${ }^{30}$. They believe that the Fury uses the scourge in order to make the girl on her left, the nubenda, fertile. According to Rizzo ${ }^{31}$, however, the passage of Pausanias concerning Alea confirms indeed the existence of whipping rituals in Greek religion ${ }^{32}$ but these have nothing to do with the Pompeian fresco ${ }^{33}$. As regards Turcan ${ }^{34}$, he argues that Pausanias does not mention Maenads and does not imply a mysteric value of that ritual. Moreover, he observes that in the Lupercalia men were whipped as well as women ${ }^{35}$ and the latter offered the whip not their backs but their hands ${ }^{36}$. Rizzo believes that the winged figure is rather in relation with the woman painted on its left who is unveiling the Dionysiac liknon, a veiled basket containing a sacred phallus, involved in Dionysiac initiations: therefore, the winged figure is supposed to be a mysterious being hostile to the initiation ${ }^{37}$. He thinks that the whole fresco evokes "Orphic-Dionysiac" conceptions ${ }^{38}$. In his opinion the winged figure mirrors the Orphic con-

Indeed, according to him the scholiast mixes up Agrae and Melite. Macchioro believes that the aim of this practice was to make the neophyte to experience the same passion of the god with whom he/she identified him/herself. Furthermore, he argues that the whipping wet the altar with human blood without any sacrifice. The final result of the whipping had a magical effect of renovation, wealth, health and happiness, not only of the mankind but also of the energies of nature. He quoted, as an example of this, a rite in honour of Demeter performed at Pheneus (Arcadia), where a priest, with a mask of the goddess, used to beat the earth with a verge: Paus. VIII, 15, 3. Such an interpretation of renovation has been to some extent reaffirmed very recently by AMIRI 2009: he considers the act performed by the Fury a symbol of the initiatic rebirth.

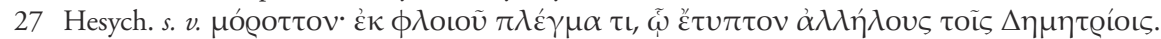

28 PICARD 1954.

29 Simon 1961: she thought that the winged goddess is a representation of the constellation of the Virgo.

30 Toynbee 1929 and Bieber 1928.

31 Rizzo 1918, 80-88.

32 He thinks that these rites were typical of Orphic cults and mentions as a parallel the ritual of the Lupercalia, too.

33 According to him the verb $\mu \alpha \sigma \tau \uparrow \gamma o \tilde{v} v \tau \alpha \iota$ indicates reciprocity and not a passive action. In order to demonstrate that,

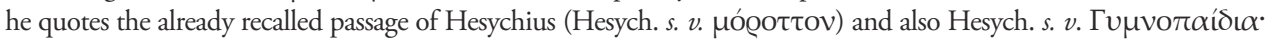

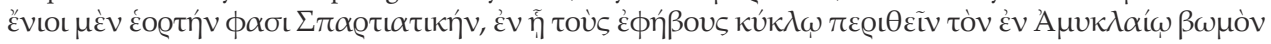
$\tau u ́ \pi \tau$ ov $\tau \alpha \varsigma \dot{\alpha} \lambda \lambda \dot{\eta} \lambda \omega \nu \tau \dot{\alpha} v \tilde{\omega} \tau \alpha$. Indeed Hesychius uses the pronoun of reciprocity $\dot{\alpha} \lambda \lambda \dot{\eta} \lambda$ ot.

34 Turcan 1982.

35 Plut. Rom. 21, 7; Caes. 61, 2.

36 Iuv. II, 142.

37 As a parallel of the scene of the Pompeian fresco Rizzo mentions the iconography of two architectonic terracottas and two Hellenistic cameos, which similarly show a woman unveiling a liknon and a winged figure who escapes as a consequence: Rizzo 1918, 128, pict. 35 and 36.

38 Indeed, Orphism provided both the Dionysiac and Eleusinian rituals - at Eleusis Dionysus was an important element at a rather ancient stage: see, e.g., SFAMENI GaSPARRo 1986, 114-122 - with a sort of theological systematization. A crucial stage of such a phenomenon occurred in Ptolemaic Alexandria: we know that Ptolemaeus IV promoted a reorganization of the Dionysiac Alexandrine guilds and ordered each of them to be provided with a hieros logos (BGU VI, 1211 (SCHUBART) = Orphicorum fr. 44 T Bernabé: Bernabé considers this passage as a proof de ritibus carminibusque sacris Orphicis vel Bacchicis quibus Aegyptia origo tribuitur). As suggested by the Orphic myths concerning Semele and Dionysus' death, rebirth and apotheosis (in these accounts the god is called Dionysus/Zagreus), Dionysism took from Orphism the conception of the beatitude post mortem for the initiates into the rites: if an initiate died he became a Bacchus (on the myth of Dionysos/Zagreus' murder by the Titans 
ception concerning an opposition between the divine nature of the human soul and occult forces. These forces try to bind the souls to the cycle of reincarnation ${ }^{39}$. The Orphic religion represented such hostile power by means of a few characters, such as Dike, the Moirai and the Furies ${ }^{40}$. Such an Orphic hypothesis was followed by many other scholars, but had several opponents. The first was Comparetti, who denied that the Dionysiac frieze has a religious and mystic meaning ${ }^{41}$. A strong anti-Orphic interpretation has been recently claimed by Veyne who, identifying the winged figure with Nemesis ${ }^{42}$, thinks that her function is only that of ensuring the secrecy of the bridal chamber.

Schefold, on the other hand, interprets the whipping as a symbolic representation of the neophyte's enthousiasmos ${ }^{43}$. A similar idea is supported by Boyancé ${ }^{44}$, who finds a satisfactory parallelism with Mene, a goddess connected to the circle of the Erinyes ${ }^{45}$. Grieco follows the interpretation of the winged figure as a Fury ${ }^{46}$, insisting on the exciting value of the whipping. This idea is also shared by Merkelbach ${ }^{47}$ and Brendel ${ }^{48}$, who interprets the goddess as Lyssa ${ }^{49}$. Margherita Guarducci supports the interpretation of the goddess as the symbol of the Bacchic fury ${ }^{50}$. She also shares the hypothesis that the scourge is a symbol of fecundation, albeit she follows Turcan who denies the presence of a whipping rite in the fresco ${ }^{51}$.

see e.g. Paus. VIII, 37, 5; Callimachus, fr. 643 (in SCARpi 2002, 377, A 13); Euphorio, fr. 36 (in SCARPi 2002, 377, A 14); Clem. Al. Protr. 17-18; Olymp. in Phd. I, 3, 3-14). The Orphic re-elaboration of Dionysism might have had an impact on Dionysiac rituals. This is suggested by a few sources which tell that Orpheus created mysteries evoking Dionysus/Zagreus' passion. On the basis of all these considerations, we are allowed to speak of an "Orphic-Dionysiac" category. Regarding these problems see, among others, CASADIO 1983; Casadio 1986; Casadio 1996; Casadio, Johnston 2009; Bernabé, Casadesús 2008 and Herrero de Jáuregui et al. 2011.

39 According to this scholar, the body is the prison where the men must pay the ancient sin of being born from the ashes of Titans, the murderers of Dionysus/Zagreus: Rizzo 1918, 86-87.

40 Cfr. the Orphic Hymn dedicated to the Furies: Hymn. Orph. 69 (ed. Quandt). All these roles converged on the larger concept of Ananke/Adrasteia. The latter was invoked as "Mistress" in the introduction of Orphic Hymns - Hymn. Orph. Proemio, 36 (ed. QuAndt) - and was described by Plato with clear references to the doctrines of mysteries (Phaedr. 248C).

41 Comparetti 1921: he thinks that the winged figure, stopped by the regenerative power of the phallus in the liknon, is a Fury sent by Iuno, the main antagonist of Bacchus. In his opinion, the fresco was aimed at representing only the joi de vivre of the people living in the villa, through a representation of idealized Dionysiac delights.

42 As others before him, as we are going to see.

43 SCHEFold 1952, 56 and SCHeFold 1972, 82-86.

44 BOYANCÉ $1966^{1}$

45 Nonn. Dion. XLIV, 227-229. According to Nonnus Mene acts by means of the scourge of Erinys Megera: Dion. XLIV, 208-210. In the Dionisiaca Mene is identified with lunar and chthonian deities such as Selene (XLIV, 228), Artemis, Persephone and Hekate (XLIV, 191-207: on the lunar aspects of Hekate see ILEs Johnston 1990, 29-39). As Boyancé points out, Hekate was considered a responsible of human madness like Mene. Mene provides Bacchic madness (mania) and fury ( yssa $_{\text {) }}$. Boyancé suggests that the goddess represented an ambiguous psychological condition: it could be either a divine punishment from which only the god can free, or the way to the mystic union with the god.

46 Grieco 1979.

47 Merkelbach 2003: this scholar, however, does not exclude the possibility of punitive or fecundating implications of the ritual.

48 BRENDEL 1966.

49 This idea was also adopted by Hearnshaw 1999, who interpreted the whipping as the climax of the initiation.

50 Guarducci 1993.

51 Moreover, she quotes an Ovidian passage (Ov. Epist. IV, 47), where the poet, speaking about Phaedra's love for Hippolytus, mentions the Bacchi Furiae. 
The Orphic interpretation provided by Rizzo, instead, has been developed by Macchioro. He believes that the woman unveiling the liknon is praying the winged figure in order to get the mystic union with the $\operatorname{god}^{52}$. The whipping is precisely the peak of initiation. Nilsson ${ }^{53}$ puts forward, too, an Orphic interpretation of the fresco, and yet a rather new one. He observes that the goddess wears a hunting dress - short skirt and high boots - which was typical of the Poinai. The Poinai were punishing divinities ${ }^{54}$ who have been recognized, for example, on many South-Italic vases. Nilsson identifies them with the phasmata and deimata - terrifying apparitions - mentioned in a passage by Celsus regarding some "Bacchic mysteries" scholar focuses especially on Dike, to whom the judgement of souls was usually entrusted in Orphic literature ${ }^{56}$. According to Nilsson, this punitive being is conquered by the regenerating symbol of the phallus ${ }^{57}$. He suggests that the role of Dike in the rituals was played by a disguised initiate. Such a punitive interpretation of the winged figure is followed by Turcan ${ }^{58}$, Ling $^{59}$ and Ricciardelli ${ }^{60}$. The hypothesis is also shared by Zuntz, although this scholar sees in the fresco a generic Fury rather than Dike ${ }^{61}$. Also Sarah Iles Johnston, who has recently dealt with these infernal characters, thinks that the winged figure of the "Villa dei Misteri"

52 The sacred marriage is represented by the phallus. But the winged goddess opposes the unveiling of the liknon, since she thinks that the neophyte is not yet ready and that she has to suffer before the initiation.

53 NiLsSON 1957.

54 In ancient Greek $\pi$ oเvท́ was the fine paid by the slayer to the victim's kinsmen. This term, when personified, was referred to the goddess (or goddesses) of vengeance: see, e.g., Eur. Iph. T200.

55 Celsus' passage is mentioned by Origenes (Contra Celsum, IV, 10), and concerns the affinity between the Christian notion of infernal punishments and the doctrine followed by who introduced terrifying apparitions in

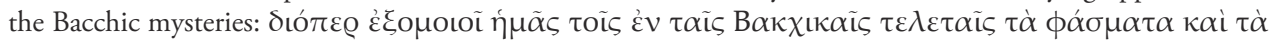

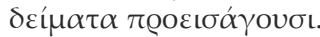

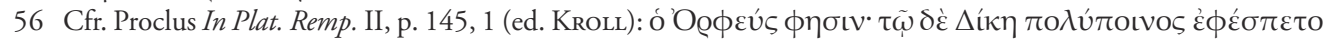

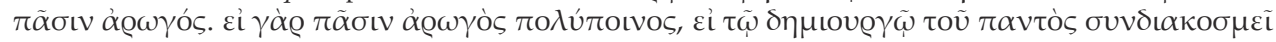



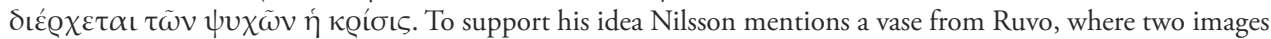
of Dike are represented, next to an enthroned Persephone, Hekate and Orpheus: one of them has a pair of wings (JATTA I906, 517-518, pl. III). He also mentions a South-Italic amphora, which shows another scene of otherwordly judgement (Wiener Vorlegeblätter, Ser. E. pl. VI, 4): here, close to the queen of the Otherworld, we can see a winged figure akin to the mysterious character of the "Villa dei Misteri". MATZ 1963 rejects the hypothesis of Dike, thinking rather of Nemesis.

57 This would be the reason why the winged figure shows disgust for the kneeling woman unveiling the liknon on its left. As Rizzo had done, Nilsson mentions the parallel iconography on the architectonic reliefs and on the cameos. He also quotes an Algerian mosaic of the $2^{\text {nd }}$ or $3^{\text {rd }}$ century AD found at Djemila, which depicts, too, a figure showing repulsion for a liknon: the analogies between the mosaic and the Pompeian fresco were underscored first by Leschi 1935/36, pls. VIII and IX), by Bendinelli 1936 and later by MatZ 1963.

58 TurCan 1969.

59 Ling 1991, 101-104.

60 See Ricciardelli 2000, 265-283: Ricciardelli is convinced that the rage shown by the Fury derives from Dionysus Child's sparagmos by the Titans. The sparagmos itself would be evoked by the phallus. The character with whip would represent therefore the punishment against men who are offspring of the guilty Titans.

61 ZunTz 1963. Nevertheless Zuntz says that the presence of Furies and punishments is odd in the Dionysiac world and this theme had to be originally Roman. Indeed, he believes that the verb used by Celsus-(Origenes)

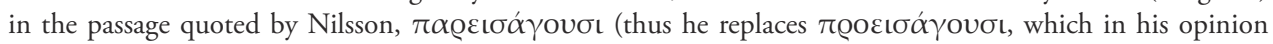
does not make sense), indicates that the terrifying presences were felt as alien in Dionysiac mysteries, even in the epoch of Celsus. Zuntz thinks that the sin sanctioned by the whipping is that of an adulterous girl. According to him this theme is consistent with the moral and the ideology of marriage of the Augustan age. 
is one of the phasmata mentioned by Celsus-(Origenes). She persuasively argues that such "ghostly manifestations" may have been a standard feature of mystery cults, which were directly concerned with the Underworld and its inhabitants, and ensured that the initiate was immune to infernal dangers ${ }^{62}$. Lehmann, on the contrary, suggests a different interpretation by a comparison between the winged figure and a similar figure from an Egyptian tomb with a graffito which labels it as Agnoia ${ }^{63}$. On the other hand, Marsoner ${ }^{64}$ strongly reaffirms the Orphic meaning of the fresco and believes that the winged figure is Nemesis ${ }^{65}$ who whips a noninitiate servant girl ${ }^{66}$. Gilles Sauron ${ }^{67}$ considers, too, the winged goddess Nemesis and quotes as a parallel the Etruscan Vanth, a goddess who appears in several Etruscan funerary paintings. Nevertheless, he refuses the Orphic interpretation, and believes that the fresco evokes the mythical story of Semele.

Given such a diversity and the contradictions of the scholarly positions, it is quite evident that further considerations are allowed if new important evidence is put forward.

\section{Problems of the status of the image and its relation with the Dionysiac phenomenon}

A $s$ we have seen, the presence of the whip has been interpreted as a reference to a punitive ritual or to a practice of expiation and/or initiation. Furthermore, there is the "Lupercal" interpretation, which argues that the whipping has a fecundating meaning. Thirdly, the interpretation of the whipping as a stimulus to Bacchic enthousiasmos definitely stands out.

The "Lupercal" hypothesis is consistent with the hierogamy - sacred marriage - in the central part of the fresco. Indeed, as most scholars do, I recognize in the woman flanking Dionysus

62 Iles Johnston 1999, 136-137). She translates the word phasmata with "ghosts" (XIX). In Greek phasma, $\phi \alpha ́ \sigma \mu \alpha$, has the same root as the verb $\phi \alpha i ́ v \omega$, "to appear": therefore, phasmata can be generally translated as "appearances". Such appearances evoke a legend reported by Diodorus Siculus, who mentions a few punishments introduced by Orpheus in the Hades on the basis of the Egyptian funerary traditions (I, 96, 4-5: see SCARPI 2002, 429).

63 Lehmann 1962, 62-68. In his opinion Agnoia in the "Villa dei Misteri" represents the sad condition of not yet initiated women. This interpretation will be followed by ETIENNE 1966, 270-272 and criticised by BoyANCÉ I966 190 and Grieco 1979, 430.

64 Marsoner 1989/1990.

65 This idea is already in Leschi 1935/36 and Matz I963. As we have seen, Veyne also identifies the Fury with Nemesis, though he refuses an Orphic interpretation of the fresco: in Veyne, Lissarrague, Frontisi-Ducroux 2003. Marsoner bases his hypothesis on a passage of Pausanias (I, 33, 7): Neither this nor any other ancient statue of Nemesis has wings, for not even the holiest wooden images of the Smyrnaeans have them, but later artists, convinced that the goddess manifests herself most as a consequence of love, give wings to Nemesis as they do to Love: transl. by W.H.S. Jones and H.A. Ormerod. Indeed, the passage confirms the existence of an iconography of Nemesis with wings.

66 Furthermore, Marsoner connects the scene to the myth of Bona Dea, where the goddess was beaten and killed by her husband Faunus after drinking some wine. Therefore, he thinks that the beaten girl symbolises either a non-initiate person or the patroness of the mystery celebrated by the fresco, who in his opinion is Kore-Ariadne. He believes that the whipping has an expiatory value. A god replaces a human being in order to atone for his sins. The neophyte identifies herself with the goddess who finally manages to get away from the revenge of Nemesis.

67 Sauron 1998. 
Ariadne ${ }^{68}$, rather than Semele, as believed instead by Boyancé and Sauron ${ }^{69}$. From this point of view the winged figure can be consequently interpreted as the dark side of the initiation into love, since the first love experience implies fear and feelings of guilt and death. But this "shock" is required to produce fertility and renovation of the family. Does the scourge kept by our winged figure hint at that idea ${ }^{70}$ ? This interpretation is weakened by the fact that in the fresco lashes are inflicted by a feminine figure which does not fit a fecundating role. Furthermore, in the clearest mythical example of fecundating whipping - i.e. the episode of Faunus whipping Bona Dea - lashes are inflicted with a myrtle branch, a plant of Venus, whereas in the fresco the material of the branch does not seem important.

On the other hand, the punitive and expiatory hypotheses imply symbolic levels which seem to be in contrast to the concreteness of the fresco. Indeed, it seems quite hard (though still possible) to demonstrate with certainty that the mistress or the master of the Pompeian villa had in mind precisely the sparagmos of Dionysus by the Titans, described by the sophisticated Orphic doctrines. Moreover, as regards the identification of the winged character with one of the terrifying presences which appeared during Bacchic mysteries, we have no further information regarding these events than the passage of Celsus - who lived in the $2^{\text {nd }}$ century $\mathrm{AD}$, almost two centuries after the fresco was painted - quoted by Origenes. The interpretation of the whipping as a stimulus to Bacchic fury seems to be more immediate, since a somewhat "common sense" makes us think that a whipping act should be stimulating ${ }^{71}$. Moreover, according to literary sources which widely circulated within the Roman context just a few decades after the realization of our fresco, the Furies are consistent with the action of awakening the Bacchic furor through stimulation. We find a poetic description of a stimulating practice in the Vergilian account of the Bacchic-like possession of Amata, provoked by Iuno by means of the stimuli of Fury Allectus ${ }^{72}$. I also recall the passage by Ovid where the myth of Ino/Leucothea, the most important among Dionysus's nurses, is mentioned. Ino's Bacchic madness is also provoked by a Fury summoned by Iuno, through her snakes ${ }^{73}$. Furthermore, Ovid's myth describes the insanity of the Ausonian Maenads, whom Ino, exiled with her son Melicertes, met in the lucus Stimulae: their madness is provoked, too, by Iuno $^{74}$. Therefore, we learn that

68 See Scapini 2016a, 204.

69 Boyancé 1966 and SAURON 1998.

70 The same concept was proposed by ancient rites of fertility, first of all that of the Lupercalia.

71 This hypothesis is supported by a passage of Plutarch (though this author, like Celsus, had his floruit many decades after the realization of our fresco), where Dionysus gives the drunkards a ferula to prevent them from getting hurt: Plut. Symp. VII, 10. See TorTorelli GHidini 2000, part. 257.

72 Verg. Aen. VII, 341-405, part. 404-405: talem inter siluas, inter deserta ferarum reginam Allecto stimulis agit undique Bacchi. For this theme see Bettini 1986, 107-109, and Mastrocinque 2014.

73 Ov. Met. IV, 488-499.

74 Ov. Fast. VI, 475-562. De Cazanove I 983 carefully analyses this legend suggesting that it mirrored a ritual of Bacchic stimulation in Maenadic ceremonies at lucus Stimulae: he repeats that the stimulating function was fully consistent with the Furies. The scholar recalls that Varro connected the name Stimula to the stimulus, a spur to beat oxen and horses. According to him, Stimula is the goddess of "exaggerated act" (Varro in Aug. Civ. IV, 11), albeit Mart. Cap. VIII, 887 considers Stimula the goddess of sexual desire and marriage. According to DE Cazanove 1983, 72-73, the Romans interpreted the stimulating function as a divine possession which leads to the ritual action. He believes that at a certain point this ancient typology of possession symbolized by the stimulus was reinterpreted in a Dionysiac form: the Roman stimulus was assimilated to the Dionysiac oĩot@os which, like the stimulus, indicated both the goad to drive cattle and anything that could drive mad: Il n'y a pas de ménadisme sans stimulation, pas d'extase dionysiaque sans la cuisante piqûre de l'aiguillon (101). 
according to the ancients - and, more precisely, in the same geographical and chronological context as our fresco - the stimulation provided by the Furies could awaken a Bacchic-like ecstasy: such a consideration may clarify the presence of the winged goddess in our painting, which was realized just few decades before the floruit of Vergil and Ovid.

Now we might ask whether the whipping act in the fresco had just a mythological meaning, and/or a symbolic value - that is to say that the picture referred to a particular meaning, to a more or less abstract concept: the awakening of a Dionysiac ecstasy in this case - and/or evoked a ritual actually practised. Such a question has been frequently posed by the scholars. We can follow three different ways. It is possible that the visual image does not mirror any ritual at all: this is, for example, the idea of Turcan. Others accept that certain themes in the fresco may reflect ritual performances, with the exception of the whipping. The third possibility is that the client asked the artist to represent something actually performed in Dionysiac rituals which literary sources do not mention ${ }^{75}$. This idea can be justified if we consider that we have a very superficial knowledge of the rituals of the ancients. No doubt, the choice of one of these positions implies a particular interpretation of the status of the image under consideration in the domestic Pompeian context: it is a matter of iconology ${ }^{76}$.

Pictures referring to the "Dionysiac world" pose a major problem when it comes to clarify their meanings and their status, since Dionysism was (also) a religious phenomenon. In this respect, Elsner's interpretation of the relationship between art and religion is worth recalling. This scholar believes that in Rome traditional religion was partly built up precisely by means of pictures: in this sense, art itself was religion. Regarding the Roman world, Elsner also argues that what he calls "religious art", the expression of traditional religion, was mimetic - that is to say, it depicted real ritual practices - whereas "mysteric art", i. e. works of art linked to mysteries, was symbolic: it used symbols to express meanings ${ }^{77}$. Should we follow this interpretation, we would be inclined to look at the whipping scene as a symbolic representation and nothing more. Can we add something regarding the meaning of this "symbol"? More precisely, what can be said regarding the "Dionysiac symbolism"? What did it refer to? As I have suggested above, the winged figured may well have represented the idea of the awakening of a Bacchic ecstasy. On the other hand, should we entirely rule out the possibility that the work of art under examination was to some extent mimetic and mirrored an act actually performed? After all, we cannot be sure that the possible rituals evoked in the "Villa dei Misteri" - if any rituals were evoked at all - were mysteries in the strict sense.

Regarding the relationship between pictures in Roman (and Greek) art and religion, I find further interesting contributions within the project Image et Religion promoted in 1999 by a group of researchers linked to the École Française of Rome. This project has included a conference entitled Image et religion dans l'espace domestique held in Athens in 2003. As underlined by $\mathrm{R}$. Robert ${ }^{78}$, in that circumstance many scholars argued that the meaning of domestic pictures in Greek and Roman art is elusive and "at the border of religion". More precisely, he speaks of a lost of meaning, déperdition du sens, a banalization of the represented themes, as

75 Indeed, we have already seen that the literary sources on whipping in rituals are not so clear and anyway are scarce.

76 I have dealt with these problems in the already quoted ScApINI 2016a, where I provide many recent bibliographical references. A very recent study on iconology in ancient art is Lorenz 2016.

77 ELSNER 1995 and 1996.

78 Quoted in Estienne, Jaillard, Lubtchansky, Pouzadoux 2008, 411. 
far as religion is concerned. Robert also focuses on the problem of the iconographical associations in domestic spaces ${ }^{79}$. By recalling a few scholarly positions - and Zanker's above all - he points out that a scattered distribution on domestic walls has been usually taken as a criterion to rule out the religious implications of pictures. Further interesting points are put forward by Jaccottet. She observes that the difference between what we consider a mythological scene and a realistic expression of ritual objects and acts is a modern schematization which the ancients may well have bypassed or not perceived at all ${ }^{80}$. Robert has also underlined that it is hard to find the difference between ce qui procède du religieux ou des cultes civiques et ce qui relève plus largement de la spiritualite ${ }^{81}$.

No doubt, we can apply these observations to Dionysiac pictures ${ }^{82}$. Indeed, as pointed out by Jaccottet, the Dionysiac themes, which are so common in very different iconographic contexts (frescoes, sarcophagi, pottery, stucco reliefs, statues, mosaics), may well be considered as expressions of an "imagery", rather than a religious manifestation ${ }^{83}$. Jaccottet also argues that many Dionysiac pictures traditionally linked to mysteries may be simple products of artistic conventions, topoi, within a very old iconographic tradition - in this case we may speak of a sort of cultural Dionysiac iconographical koiné - rather than allusions to real rituals. More recently, Stéphanie Wyler has expressed a similar idea. She believes - including in her analysis the fresco of the "Villa dei Misteri" - that many domestic Dionysiac representations are a mise en scène de type générique ${ }^{84}$. According to her, we deal in these cases with images dionysiaques aux limites $d u$ religieux, with a religious atmosphere rather than with pictures linked to mysteries in a strict sense and/or to a precise ritual ${ }^{85}$.

That said, and although nowadays we all agree that we cannot consider these pictures traditionally linked to mysteries as mere photographs of rites, many scholars are still convinced that they express strictly religious meanings and depict - at least allusively and symbolically - aspects of Dionysiac initiation (and/or mysteric) rituals. Turcan's book published in 2003 and devoted to the Bacchich liturgies in Rome is a sort of arrival point of such an interpretative attitude ${ }^{86}$. As the title of his study indicates, the iconographic documents, the documentation figurée, are considered therein, along with literature and epigraphy, as an important historiographical source in order to explore these rituals. I find Turcan's perspective particularly stimulating, and I take it as the methodological basis of my argument: it is possible that a few themes belonging to the Dionysiac iconography of the late Roman Republic say something regarding the Dionysiac rituals practised in the society which produced those documents. In the following lines I intend to further justify this perspective. First of all, however, I would like to point out that I am not

79 Regarding this specific problem in the context of Pompeii see LoREnz 2008.

80 JaCCOTTET 2003, 194-195. Also SEAFORD 2006, 72.

81 Estienne, Jaillard, Lubtchansky, Pouzadoux 2008, 414.

82 What is more, as Robert himself has underlined, the debate concerning the value of iconography - sacred $v s$ merely decorative - has focused especially on Dionysiac iconography.

83 JАССОтТет 2003, 195.

84 WyLER 2008, 458.

85 Among her works on these themes see also WYLER 2004. Recently I have also devoted a few works to Dionysiac iconography and its meaning in Rome between the late Republic and the Empire: besides the already quoted book (SCAPINi 2016a), see my article SCAPINI 2016b. Here I describe several literary and iconographic documents attesting the resounding success of a few Dionysian themes and, more generally, the vitality of Dionysism in the Augustan age, by quoting many recent studies on this theme (among them see, e.g., MaC GóráIN 2013).

86 Turcan 2003. 
referring to the whole Dionysiac iconography, a long-lasting phenomenon, characterized by a great variability in space and time. I only refer to the Roman domestic iconography of the late Republic, which is the cultural environment of the iconography under scrutiny.

The point is that many pictures belonging to Dionysiac late-republican and proto-imperial domestic iconography ${ }^{87}$ depict - according to rather homogeneous and repetitive thematic and stylistic patterns ${ }^{88}$ - characters involved in rituals more or less linked to Dionysism, implying veiled figures (often children), dances, musical instruments, scenes that have been interpreted as divination rites, sacrifices - often of pigs - and containers of phallic simulacra such as likna and cista mysticae. I do not see enough reasons to rule out the possibility that these pictures had some relationship with a very common phenomenon in the Roman world, from the late Republic onwards, that is the Dionysiac associations ${ }^{89}$, private organizations open to men and women that practised Dionysiac rituals with variations on the basis of the different interests of each group. The point is that themes such as likna and cistae mysticae did exist in the rituals practised by the associations and that sacrifices, initiations and children were involved therein, as we learn from the epigraphic corpus ${ }^{90}$. As demonstrated by Turcan and Jaccottet ${ }^{91}$, these associations shared elements of the mystic Dionysism elaborated in Hellenistic Alexandria, where Dionysiac themes mingle with Eleusinian issues and the Orphic doctrine. As such, I believe it is reasonable to connect the works of art under scrutiny to the rites practised by Dionysiac associations. No doubt, using Elsner's schematization, it is hardly possible to demonstrate that iconographic themes such as veiled acolytes, likna and cistae mysticae were strictly mimetic. Nevertheless I do not find elements enough to exclude a certain connection between them and rituals which were so common in the same geographical and chronological context.

A similar conclusion may well be applied to the Dionysiac repertoire of the "Villa dei Misteri" (not only the megalography ${ }^{92}$ ), which also includes similar themes, and to the particular scene under examination. No doubt, it is hardly possible to identify with certainty a specific Dionysiac ritual which this repertoire might refer to: should we think of a rite practised by an association? Of course, we may also deal with a sort of pastiche of ritual acts practised in different ceremonies. Elsewhere, I suggest that a specific exclusively female ritual - implying female initiations into marriage in a Dionysiac form, echoed, as we have seen, by the Diony-

87 Besides the megalography of the "Villa dei Misteri" itself, and other frescoes found in the same Villa, see, for example, the pinakes of the "casa del Criptoportico" in Pompeii, and a few frescoes of Nero's Domus Aurea and the pinakes of the "Casa della Farnesina" in Rome.

88 Although this aspect, of course, cannot be taken as a proof that the rituals which may be evoked in these pictures were homogeneous themselves: they might simply have shared a few themes.

89 Besides the ancient public cult of the Aventine triad, composed by Ceres, Liber and Libera, between the $1^{\text {st }}$ century $\mathrm{BC}$ and the $1^{\text {st }} \mathrm{AD}$ the Dionysiac cult in Italy was basically a private phenomenon, whose core was precisely private associationism: see WYLER $2008^{1}, 61$.

90 Suffice it to recall the well known "Inscription of Agrippinilla", which concerns the activities of a Dionysiac association, now at the Metropolitan Museum, where all these elements are recalled: on this document see, among many others, Ricciardelli 2000, 270-271; JaCCOTtet 2003; MerkelbaCh 2003, 27-28.

91 Turcan 2003 (also Turcan 1992 and 2004, 290-298) and JасCOTtet 2003.

92 In SCAPINI 2016a, 185-231, I thoroughly examine the whole iconographic repertoire of the Villa, which includes a cista mystica and other pictures of Maenads, Satyrs and Dionysus dated to the same years as the megalography. In the same pages an up-to-date bibliography on that context is provided: among the most recent works dealing with the above mentioned problems regarding the contextualization and definition of the status of domestic pictures see, e. g., GAZDA 2000. 
siac hierogamy - might be evoked at least in the room of the megalography ${ }^{93}$. Here, however, I do not intend to deal with this problem. I just want to investigate a possible ritual act - more precisely, a whipping ritual - which may have been performed in more Dionysiac rituals, no matter if within a particular association (involving both men and women), or during an exclusively female rite centred on a Dionysiac hierogamy. In the following paragraph I will point out within the ancient sources - both literary and iconographic - further possible allusions to an actual stimulating whipping in Dionysiac rituals ${ }^{94}$.

\section{The spinning top as an image of Dionysiac ecstasy}

$\mathrm{F}$ rom a preliminary research throughout literary sources, I have gathered very interesting data. According to the ancients, the spinning top, commonly called $\beta \dot{\varepsilon} \mu \beta \eta \xi / \beta \varepsilon \dot{\varepsilon} \mu \beta$

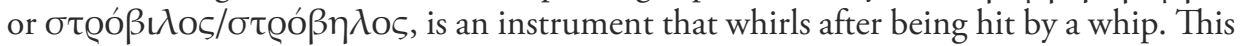
process is particularly clear in the Suda ${ }^{95}$ :


streets children that beat (v́rò $\pi \lambda \eta \gamma \tilde{\eta} \sigma \iota)$ the spinning tops in order to make them whirl. (...) The spinning top is an object which children make whirl by means of a whip. Or a children toy, as a hoop, that turns when beaten by a whip (ôs $\mu \alpha \dot{\sigma} \sigma \tau \uparrow \mathrm{t}$

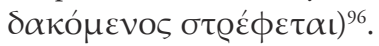

We can find the same assumption in a passage by Michael Psellus ${ }^{97}$ :


leather scourge makes whirl.

The connection between whip and spinning top is already expressed in Aristophanes ${ }^{98}$ :

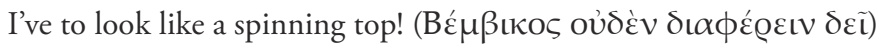

93 See SCAPINI 2016a, 185-231 and above all 204-207.

94 The analysis of the status of the imagine under scrutiny also implies considering the iconographic parallels of our winged figure. I have examined them in detail in a further article (SCAPINI 2012/2013). It may be worth considering the winged female characters in Dionysiac contexts that appear elsewhere in the houses of Pompeii. Winged characters are depicted, for instance, in the quite common Pompeian frescoes representing Dionysus discovering Ariadne asleep. These characters have been interpreted as mythological personifications (the Nemesis of Theseus or Hypnos: concerning the iconography of abandoned Ariadne see GALlo 1988), as Lasae (RICHARDSON 1979,194 ) or as generic symbolical presences with a supporting role in the divine marriage (SIMON I96I). Also in these cases the main role of the winged character - more or less identifiable with a deity or a mythological presence - is the representation of a particular idea or conception: in this sense therefore, its function is mainly symbolic. As such, we can conclude once more that the winged figure in the "Villa dei Misteri", too, was aimed at representing a particular conception, presumably a Dionysiac possession, which was symbolically related - as Cazanove has very clearly demonstrated - to a stimulating whipping.

95 S. v. $\beta \varepsilon \dot{\varepsilon} \mu \beta \eta \xi$. See also Diog. Laert. I, 80 and Callimach. Epigr. I, 9.

96 Regarding children's toys in the Greek and Roman world see DASEN, SCHÄDler 2013.

97 Opuscula psychologica, theologica, daemonologica, p. 133, line 17 (ed. O'MeAra).

98 Av. 1464-1466. 
I understand... a spinning top! Yes! I have here, by Jupiter these beautiful wings from Corcyra!

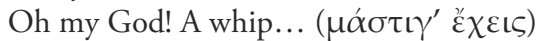

Wings they are! And with these I will make you turn!

Poor me!

It is quite clear from these passages that the whip was the cause of a whirling movement. The wide chronological range of these sources suggest that such an association was quite common in the Greek world. The Suda connects the $\mu \alpha \dot{\alpha} \sigma \tau \xi \xi$, which provokes the spinning, to the


substantive $\pi \lambda \eta \gamma \eta^{99}$. Furthermore, other sources connect the $\mu \alpha \dot{\alpha} \sigma \tau \iota \xi$ to the verb $\tau u ́ \tau \tau \omega^{100}$. All these words lead us to the second meaning of the term $\beta \varepsilon \dot{\varepsilon} \mu \eta \xi$ attested by the sources, that is "hornet", since painful $\pi \lambda \eta \gamma \varepsilon$ í $\varsigma$ were also attributed to such an insect ${ }^{101}$. The use of the word $\beta \varepsilon \dot{\varepsilon} \mu \eta \xi$, spinning top, in order to indicate the insect is likely connected to the rapid trajectories followed by these animals ${ }^{102}$. Nevertheless it seems interesting that according to the ancients the $\pi \lambda \eta \gamma \varepsilon$ í $\zeta$ of insects like the $\beta \dot{\varepsilon} \mu \beta \eta \xi$ could provoke a divine madness ${ }^{103}$, that such a madness was often metaphorically described as the $\pi \lambda \eta \gamma \varepsilon \dot{c} \varsigma$ of a $\mu \alpha \dot{\alpha} \sigma \tau \xi$, and that the latter was the very instrument used in order to make a spinning top/ $\beta \varepsilon \dot{\varepsilon} \mu \beta \eta \xi$ whirl. It seems that we are dealing with a paradox without a solution, and this suggests that we are facing a conception which is no longer understood.

The most famous example of madness provoked by an insect is provided by the story of

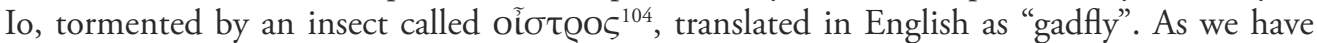
already seen following De Cazanove, the same word - such as the Latin stimulus - was also used in order to indicate cattle goads and the weapon that mythical infernal Furies used in order to drive people mad and provoke a Dionysiac-like madness. Consistently, Io's madness has a strong Dionysiac imprint ${ }^{105}$. As we learn from the literary description of Io's Dionysiaclike mania and of the similar possessions of the Proetides, Ino, and Amata, according to the Greek and the Roman authors this experience was characterised by - if not based on - a frantic wandering implying whirling movements in circle, a combination of movements typical of the $\beta \varepsilon \dot{\varepsilon} \mu \beta \eta \xi$ (both the spinning top and the hornet). Amata's Dionysiac-like ecstasy (Vergil, VII, 385 , writes simulato numine Bacchi), for instance, is described by the poet ${ }^{106}$ in this way:

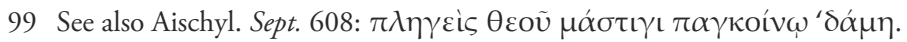

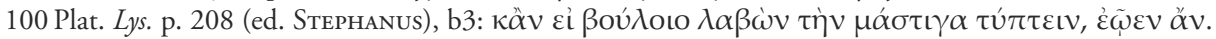

101 Eutecnius writes in his Paraphrasis in Nicandri Theriaca (805-816) that he knows the following regarding the

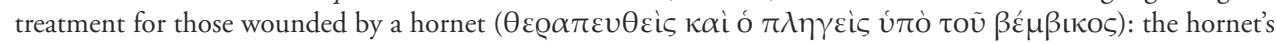
bite ( $\tau$ ò $\pi \lambda \tilde{\eta} \gamma \mu \alpha$ ) is very painful, but immediately subsides when you pull out his sting.

102 Moreover, as LeVANiouk 2007 points out, both spinning toys - such as our spinning top but also the @ó $\mu$ ßo - and buzzing insects, as the hornet, produce a buzzing sound.

103 As I have demonstrated in SCAPINI 2016 (forthcoming).

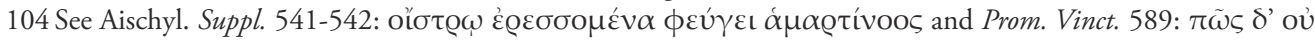

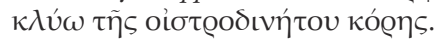

105 See CASADIO 1994, 64 (footnote 18), who suggests that the madness experienced by the cow-Io was modeled precisely on the mythical model of the Maenad. On these themes see again SCAPINI 2016 (forthcoming). In this work I point out that the madness of Io and those, very similar, of other women of the myth (the daughters of Proetus, Ino and the

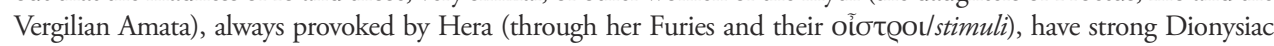

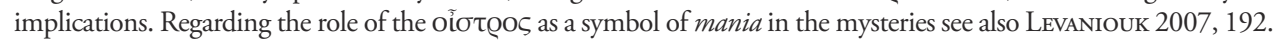
106 Verg. Aen. VII, 378-383. 
(...) She went throughout all the great city as / sometimes a spinning top, whipped by a twisted / lash, is driven in great circles through empty halls by / children intent on their game: the top, pulled by a rope, / moves in curved patterns, and the innocent group of boys, / stricken with awa, gaze at the whirling toy, and their whips give it / even more $^{107}$.

Thereby, on the rather logical premise that the myth should tell at least something of an actual rite, we can assume that movements like these were performed in real Dionysiac rituals by acolytes who both rotated about their axis and followed a chaotic trajectory ${ }^{108}$. After all, we have already seen that dance was an important element of Dionysiac rituals: that these dances implied movements promoting ecstatic feelings does not come as a surprise.

Now, what can we say of the clinical causes of this peculiar movement? As we have seen, in myths the causes are either stings of insects or stimuli of the Furies (which are often superimposed with snakes, as in the case of the "viper" of Amata, especially in iconography), both being on a par to each other for their stimulating role. It seems rather hard - but still possible - to conclude that such "animal/instruments" were used in real rituals. We are allowed to suppose that such a mysterious stimulating instrument in rituals was nothing but the whip, the object to which the ancients refer actions such as $\delta \alpha \dot{\kappa} \nu \varepsilon \iota \nu$ and $\pi \lambda \eta \sigma \sigma \varepsilon \varepsilon \nu$, typical of "Dionysiac" hornets and - we can add - snakes. Moreover, if Dionysiac acolytes moved like spinning tops, the passages quoted above demonstrate that in the ancient everyday life spinning tops could not whirl without the strokes of a whip. From a physiological point of view, it is quite clear that it was the whirling movement, and not the whipping itself, to provoke the Dionysiac delirium ${ }^{109}$ : the whipping was simply the action strictly associated to the "spinning top movement". Therefore, whipping may well have been symbolically performed or at least evoked in the actual rituals in order to recall (rather than produce) ${ }^{110}$ a dance preliminary to the Dionysiac possession, which combined an about-the-axis rotation and a chaotic trajectory.

Someone could observe that the analogy between the Bacchic-like possession of Amata and the spinning top enhanced by Vergilius could be nothing but a literary metaphor ${ }^{11}$. Neverthe-

107 Transl. by P. Johnston. Magdalena von Duhn provide us with an excellent comment on die Gleichnisse (the parables) of Amata, pointing out that the comparison with the spinning top symbolizes the overthrow of order in Latinus's palace provoked by Iuno (VoN DuHN 1957). When the cause of the madness is an insect, as in the case of Io, it might have been also a superimposition of "subject" - the insect - and "object" - the woman. The

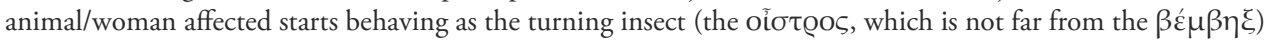
which has bitten her. This may partially explain the paradox I have described above. Regarding such themes see again my ScAPINI 2016 (forthcoming).

108 Spinning top differs from other symbolic devices which embodied, too, aspects of the ecstatic experience (such as the rhombos and the iynx) precisely by virtue of its movement, which combines an about-the-axis whirling and a no-direction movement within the space, whereas the rhombos and the iynx are always tied to a cord. On the rhombos see Levaniouk 2007. On the iynx and its symbolism see Faraone 1993 and 1999, 55-69, and Iles Johnston 1995, who persuasively argues that the power of the iynx-wheels lays in the sound they produce. Something analogous may well be argued regarding the rhombos which produces, too, a "buzzing" sound, as we have seen following LEvaniouk 2007. On the contrary, the most remarkable characteristic of spinning tops is their movement, and not - of course - their sound. Nevertheless, as underlined by FaraONE 1999, 63, footnote 102, from the late Hellenistic period onward these devices were confused.

109 Although the ecstatic value of the pain cannot absolutely been excluded.

110 In the same way as a teacher calls out a pas in a dance school.

111 I may be worth recalling S. Iles Johnston considerations concerning the "iynx spell" (the iynx was a device that, 
less, that dances evoking the spinning top movement did exist in the Greek and Roman world is confirmed both by literary sources and iconography. Indeed, ancient authors state that the

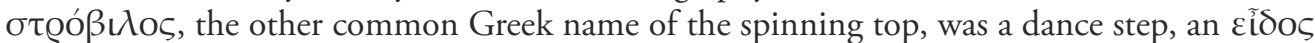

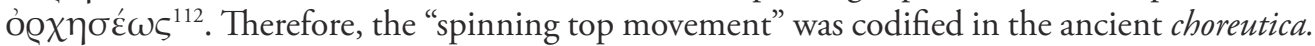
The presence of the "spinning top" choreography in codified komastic dances is confirmed by a passage of Aristophanes's Wasps ${ }^{113}$. As such, it seems that we are dealing with quite ancient phenomena and conceptions. The iconography of the Maenads on Greek and Italian vases confirms the importance of this whirling movement both in the Greek and the Roman world ${ }^{114}$.

These considerations strengthen my interpretation of the ambiguous scene on the fresco of the "Villa dei Misteri" as an allusion to a whipping (actual or imagined) evoking the incipit of a Bacchic "whirling ecstasy". In Greek and Roman imagination this action might well have been prompted by a Fury of Hera/Iuno, as it happened in the case of Io, Ino, the Proetides, and Amata. Someone could observe that in all these cases we are dealing with a perverted Dionysism, the dark side of Dionysus's worship, and this is not consistent with the atmosphere of the Pompeian fresco. Nevertheless, we may well presume that a Fury with her stimulus was

as we have seen, at a certain point was probably confused with the spinning top): There is no reason to assume that the victim of any other iynx-wheel is to be imagined as sympathetically whirling: ILes JoHnston 1995, 181.

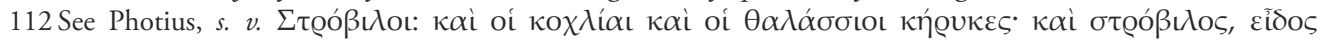

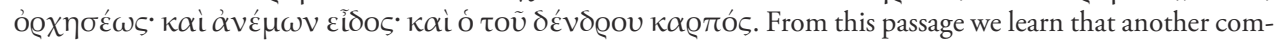


sums up two metaphors of the Dionysiac mania, namely the storm and the circular movement, and was directly evoked by both the spinning toys (the spinning top and the @ó $\mu ß 0 \varsigma$ ), which whirled and buzzed.

113 1516-1635: Come then, let's all give them a bit of room, so that they can spin themselves around before us without interference. Up, you renowned children of Sir Salty, jump along the sand and the shore of the barren sea, brethren of shrimps; whirl a swift foot all around, and someone kick out the Phrynichus caper, so that seeing the foot in the air the audience will cry ooh! Whirl! Sidle around and slap your belly; throw a leg sky high; pirouettes included

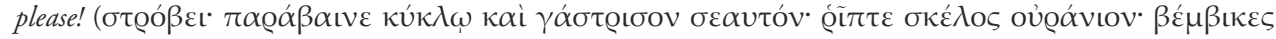
$\dot{\varepsilon} \gamma \gamma \varepsilon v \varepsilon \dot{\sigma} \sigma \omega v)$ Because the Lord and Master of the Deep scuttles hither himself, delighted with his very own children, the triple duckers! Now lead us out of here dancing, if you please, and quickly; for no one has ever done this before, to take a comic chorus off in dance: transl. by J. HeNDERSON.

114 Of course, besides women acting as "Maenads", this movement may well have been performed by other acolytes, men included. Regarding the dances performed by "Maenads" see, e.g., GaSPARrI 1986, numbers 316, 338 and 430. Yet in the 20's LAWLER 1927 has collected many Maenadic representations, trying to recognise types of dance. Her conclusion is that these scenes portray real women in Thyadic dances. Another work worthy of attention is the recent study about the origin of the Greek iconography of the Maenads until the end of Archaism, by Villanueva Puig 2009. While searching for images of Maenadic rituals interpretable as circular dances it is important to bear in mind that vase painting has to make scenes comprehensible in a two dimensional format. Every investigation on this theme shall consider this aspect. Regarding the three-dimensional scale, one of the more ancient representations of a Maenad is the famed Maenad of Skopas, which we know thanks to a Roman copy. She is portrayed in the middle of her Bacchic frenzy. Significantly, she has a gyrating pose, emphasized by her loosed hair and the swirling drapery (JOYCE 1997, 87-89). The odd presence of a spinning top in the myth of Child Dionysos (and perhaps in certain "Orphic-Dionysiac" rituals as well), along with other crepundia (see Clem. Alex. Protr. II, 17-18; Apul. Apol. LVI and Papyrus Gurob I, 29, fr. 31, ed. KerN), may well be interpreted as a further symbolic allusion to a "spinning top dance" in Dionysiac rituals: As a symbolon of the mysteries, then, the top captures not only the whipping and circular motion, but the suddenness of the attack, the confusion, fear, and pain of the neophyte, and even the contrast between the calm initiators and the frantic novices (LEVANIOUK 2007, 190). Hirst 1937, 65-66 had suggested that Vergilius had precisely in mind the Orphic toys when he described the "parables" of Amata. Already MACCHIORO 1929, 197-199, wrote regarding the probable use of objects like these in the rituals evoking the passion of Dionysos/Zagreus. 
the most effective means of representing the clinical cause of a Dionysiac possession. Indeed, it must have been difficult for the artists to depict the beginning of a whirling dance and the divine inspiration which caused it. It is worth recalling that in the fresco, after the group of the kneeling girl flanking the winged figure, a Maenad stands out and looks as if she were whirling on the spot.

\section{Erotic implications of the spinning top}

A

$s$ we have seen, in our fresco the Dionysiac ritual mingles with the erotic theme, which represents the core of the scene. The association between the world of Dionysus and Aphrodite occurs very frequently: the Dionysiac stimulus-oĩ $\sigma \tau \varrho \circ \zeta$ was connected both to an "exaggerated" act and to sexual desire ${ }^{115}$. This association was so strict that it has survived in neo-Latin vocabulary for centuries, since the word "oestrus"/"estrus" (Engl.)/"estro" (It. and Sp.)/“œstrus” (Fr.) means both a creative inspiration and the rutting period (heat) of animals. Therefore, the Dionysiac mania was conceived as very similar to the mania provoked by Eros ${ }^{116}$. It could be observed that in the fresco we do not deal with a frantic form of love, a destructive and infertile erotic mania, but with a socially codified form of love, namely a wedding. As a matter of fact, the love produced by such a stimulus in certain situations could have institutional implications, since we learn from the already recalled passage by Martianus Capella that Stimula, the goddess of the stimulus, was a patroness of wedding ${ }^{117}$. This is a very

115 As I have already recalled above, quoting De CaZanove 1983 and Varro and Martianus Capella.

116 See again Levaniouk 2007, 186. It is worth recalling also an Ovidian passage (Ov. Epist. IV, 47) recalled by GuARDucCI, 1993: it describes the Bacchi Furiae as cause of Phaedra's love for Hippolytus. Already Euripides (Hipp. 1298-1303) calls Phaedra’s passion oĩot@os. The erotic power of whipping, and its consistence within a Dionysiac atmosphere, is already celebrated in the ancient fresco of the Etruscan "Tomb of the Whipping", dated to the first decades of the $5^{\text {th }}$ century BC. Here we see komastic characters - such as musicians and dancers - who suggest an influence of the cult of Dionysus: another scene, clearly erotic, depicts two men who hits a woman with a whip and a hand in order to stimulate her. From these considerations we see that the whipping in our Pompeian fresco may well express Dionysiac enthousiasmos and stimulation of erotic passion and fertility at the same time. The erotic implications of whipping and its presence - more or less metaphorical - in Greek magic have been thoroughly studied by FARAONE 1993 and 1999, part. 60-62, where he recalls the late Roman sarcophagi that show Pan being flogged by Erotes, and interprets them as a claim of the idea that love conquers all. Faraone clearly states that the Greek erotic spells implying a "whipping" were aimed at making the beloved women act like Maenads, who are driven away from their homes and domestic duties, exactly like Amata. JoHnsTon 1995, who discusses a few interpretations of Faraone and believes that the whipping mentioned by the Greek "magical" sources was nothing but a metaphor, does not deny Faraone's considerations regarding the ambiguous symbolism of the whipping, both erotic and Dionysiac. It is worth recalling that Faraone, on the basis of the Pythian 4 of Pindar, denies that the erotic frenzy produced by the whipping was based upon whirling movements, since the


Johnston 1995, 181: as we have seen, however, this scholar believes that there is no reason to assume that the victim of the "iynx spell" is to be imagined as sympathetically whirling). No doubt, Faraone's consideration may be correct, and yet it is not very important in the case under examination, that is the fresco of the "Villa dei Misteri", which is far more recent than Pindar's Pythian and belongs to a different geographical and cultural context. In our analysis Vergil's passage on Amata is a much more meaningful correspondent, and nobody will deny that in the Aeneid frenzied Amata does whirl. I have analysed the various symbolic meanings of whipping in SCAPINI 2015.

117 Mart. Cap. VIII, 887: nec Suada inlecebris sponsalia pectora mulcet, nec Stimula incenso allicit aculeo. Here Venus speaks about the goddesses of the nuptiae: Stimula stands out among them. 
late piece of information, but significantly consistent with the fact that an important Greek female ritual of hierogamy had a recognisable Dionysiac form. It was the ceremony performed during the Anthesteria in Athens, when Dionysus met the wife of Archon Basileus in the Boukoleion ${ }^{118}$.

We have a fine document which sums up both the nuptial theme and the world of Dionysus: it is very interesting that such a connection is created through the very symbol of the spinning top. It is a $4^{\text {th }}$ century pelike from Montescaglioso, now in the Museum Domenico Ridola at Matera, and described by Trendall and Schneider-Herrmann ${ }^{119}$. The vase displays a couple of women: the one on the right is playing with a ball, whereas that on the left sits and looks at a winged Eros who makes a spinning top whirl by means of a whip. Trendall and Schneider-Herrmann explain the scene relating it to the Dionysiac world and interpreting the winged boy as a "Dionysiac Eros". We are allegedly dealing with a female initiation into love, and presumably into a wedding: the spinning top, commonly related to the world of childhood $^{120}$, somewhat represents the passage to adulthood through love and marriage ${ }^{121}$.

The spinning top is similar to the spindles for spinning fibers such as wool and cotton. As Harcourt-Smith underlines, the word $\sigma \tau \varrho o ́ \mu \beta 0 \varsigma$ - a further term indicating the spin-

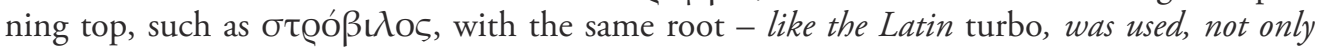
for a whip-top, but also for a spindle-whorl, rather, for a spindle fitted with its whorl. The whorl, transfixed on the end of the spindle, gives us what is practically the identical form of the whipto $p^{122}$. As the spinning tops, spindles also appear on vase paintings: they probably allude to the domestic virtues of married women. Furthermore, they were also associated with hetaerae, in order to evoke scenes of seduction ${ }^{123}$. As the spinning tops, the spindles had therefore erotic and nuptial implications. Therefore the spinning top/spindle unifies the Dionysiac, erotic and nuptial spheres which particularly interested the owners of the "Villa dei Misteri": it would make sense, should the ritual evoked in the megalography of the "Villa dei Misteri" represent a female initiation through a symbolic Dionysiac hierogamy, which I am convinced to ${ }^{124}$.

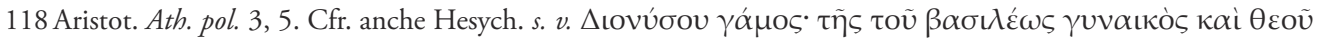

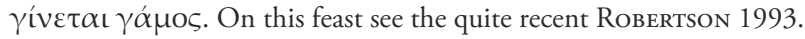

119 Trendall, G. Schneider-Herrmann 1975, 267-270 and figs. 8-11.

120 See Kastner 1995 and the already quoted Dasen, Schädler 2013. Trendall, Schneider-Herrmann 1975 recall a kylix of Brussels (Pfunl 1923, pl. 199, pict. 525) which shows a maiden with whip and spinning top.

121 See an Attic red figure lekythos depicting an adolescent youth with a spinning top flanked by Hermes, the transitional god par exellence (BEAUMONT 2012, 129-30 and fig. 4.20). Regarding the connections between the spinning top and Hermes see in particular MinTo 1925, 683-685, who explains this fact by saying that the god was the protector of children and their plays. Spinning tops, often with Dionysiac motives, were found in a few Greek sanctuaries, among other toy offers: see Trendall, Schneider-Herrmann 1975, 269 and Levaniouk 2007, 177.

122 Harcourt-Smith 1929.

123 See Rodenwaldt 1932 (contra Crome 1966, who denies that these women are hetaerae. Nevertheless, he confirms the erotic meaning of such scenes).

124 It can be observed that the spinning top and the spindle imply opposite direction of the whirl, since the yarn will be wrapped around the spindle, whereas the spinning top will be released from the whip. Such an opposition might recall the traditional prejudice rather frequent in the Greek literature according to which the Maenads were comparable to wild wasps, roaming in the wild and fond of bloody meat, in contrast with the stereotype of the good family mother, industrious as a bee (see again Scapini 2016 (forthcoming)). This literary dichotomy might be enhanced by the immediate opposition between the dissolving trajectory followed by the spinning top - characterising the anti-social Maenads - and the opposite, productive, whirling of the spindle - held by 


\title{
Conclusions
}

ll these considerations strengthen my hypothesis that the whipping figure of the "Villa
dei Misteri" hints at a whipping actually evoked in the Dionysiac rituals. Should we
deny the connection of the character with the kneeling girl on his left - and connect it with the woman unveiling the liknon - the whipping theme is still present. This practice was aimed at awakening a Dionysiac enthousiasmos, a theme perfectly consistent with the atmosphere of the fresco, and which strictly recalls the dancing Maenad on the right wall. In particular, the whipping was performed in order to prompt the acolyte to a whirling dance step. This choreography was based upon the parallelism between the dancer and a spinning top which was traditionally put in motion by a $\delta \alpha \kappa v 0 v-\pi \lambda \eta \gamma \eta \dot{~ o f ~ a n ~ o i ̃ o \tau \varrho o \varsigma-s t i m u l u s, ~ a ~ t h e m e ~ w h i c h ~}$ was also evoked by the mythical Dionysiac-like dances of women such as Amata. Its infernal shape evokes the Furies of Iuno, who commonly bear stimuli to produce a Dionysiac mania.

Moreover, the presence of a Dionysiac "spinning top dance" is also consistent with the hierogamic theme central in the fresco, since the spinning top was also connected to the female initiations (which in my opinion are evoked by the Dionysiac hierogamy) and to the symbolism of love, marriage and, more generally, of life - through the parallelism with the spindle, too. Therefore, the proposed hypothesis is also consistent with the possible nuptial value of the whipping in our fresco ${ }^{125}$, without implying a reference to the rite of the Lupercalia and the myth of Bona Dea whipped by Faunus. Both the Dionysiac and the erotic themes ${ }^{126}$ are summarised by the spinning top. As such, I believe this object represented a particularly effective kind of choreography in the rituals ${ }^{127}$ and an incredibly powerful symbol.

\author{
Marianna Scapini \\ Via Cavalcaselle 21 \\ 37124 Verona \\ marianna.scapini@gmail.com
}

virtuous women. The spindle, the instrument of Clotho, who spins the thread of life onto her spindle, is indeed strictly connected with life: Clotho has control on life and she is provided with life-giving powers, as we learn, e. g., from her role in the legend of Pelops (see Pind. O. I, 37). The complementarity between spinning top and spindle might reflect therefore the existence of a suspicious attitude towards the ancient Maenadism, which is literary mirrored in the prejudices of the Euripidean Pentheus. Such a negative interpretation of Maenadism, however, seems to be mainly a literary topos: indeed, the official status and social prestige of female Dionysiac ceremonies such as the hierogamy of the Anthesteria cannot be denied.

125 Suggested, as we have seen, by a few scholars.

126 And the initiations into the mysteries of Dionysus and those of love.

127 With a clear psychotropic effect. 


\section{Bibliography}

AMIRI 2009

B. Amiri, «De la fonction régénératrice de la démone ailée : l'imaginaire religieux de la Fresque de la villa des Mystères", Dialogues d'Histoire Ancienne 35 (2009), 81-100.

BeAumont 2012

L. A. Beaumont, Childhood in Ancient Athens: Iconography and Social History, London-New York 2012.

Bendinelli 1936

G. Bendinelli, Il fregio dionisiaco della Villa dei Misteri a Pompei, Torino 1936.

Bendinelli 1968

G. Bendinelli, "Ultime considerazioni intorno alla villa pompeiana detta dei misteri», Latomus 27 (1968), 823-831.

Bernabé, Casadesús 2008

A. Bernabé, F. Casadesús, Orfeo y la tradición órfica, Madrid 2008.

BetTini 1986

M. Bettini, Antropologia e cultura romana, Roma 1986.

Bieber 1928

M. Bieber, "Der Mysteriensaal der Villa Item», Jahrbuch des Deutschen Archäologischen Instituts 43 (1928), 298-330.

BOYANCÉ 1966

P. Boyancé, «Dionysos et Sémélé», Rendiconti della Pontificia Accademia di Archeologia 37 (1966), 79-104.

BOYANCÉ $1966^{1}$

P. BoyancÉ, "Ménè-Hécate à la villa des Mystères», Rivista di archeologia cristiana 42 (1966), 57-71.

BRENDEL 1966

O. Brendel, "Der grosse Fries in der Villa dei Misteri», Jahrbuch des Deutschen Archäologischen Instituts 81 (1966), 206-260.

BRENDEL 1980

O. J. Brendel, "The Great Frieze in the Villa of the Mysteries", in O. J. Brendel (ed.), The Visible Idea. Interpretations of Classical Art, Washington D. C. 1980, 91-138.

Casadio 1983

G. Casadio, «Per un'indagine storico-religiosa sui culti di Dioniso in relazione alla fenomenologia dei misteri, II», Studi e materiali di storia delle religioni 49 (1983), 123-149.

Casadio 1986

G. Casadio, "Adversaria orphica et orientalia», Studi e materiali di storia delle religioni 52 (1986), 291-322.
Casadio 1994

G. Casadio, Storia del culto di Dioniso in Argolide, Roma 1994.

Casadio 1996

G. Casadio, "Osiride in Grecia e Dioniso in Egitto», in I. Gallo (ed.), Plutarco e la religione, Atti del VI convegno plutarcheo (Ravello, 29-31 maggio 1995), Napoli 1996, 201-227.

Casadio, Johnston 2009

G. Casadio, P. Johnston (eds.), Mystic Cults in Magna Graecia, Austin 2009.

Comparetti 1921

D. Comparetti, Le nozze di Bacco e Arianna, Firenze 1921.

Crome 1966

J. F. Crome, «Spinnende Hetairen?», Gymnasium 73 (1966), 245-247.

DASEN, SCHÄDLER 2013

V. Dasen, U. Schädler (eds), "Jeux et jouets grécoromains", Archéothéma 31 (2013).

De Cazanove 1983

O. De Cazanove, "Lucus Stimulae», Mélanges de l'école française de Rome 95 (1983), 55-113.

De Petra 1910

G. De Petra, «Villa romana presso Pompei», Notizie degli scavi 7 (1910), 139-145.

ELSNer 1995

J. Elsner, Art and the Roman Viewer. The Transformation of Art from the Pagan World to Christianity, Cambridge 1995 .

ELSNer 1996

J. Elsner, «Image and Ritual: Reflections on the Religious Appreciation of Classical Art», Classical Quarterly 46 (1996), 515-531.

Estienne, Jaillard, Lubtchansky, Pouzadoux 2008 S. Estienne, D. Jaillard, N. Lubtchansky, Cl. Pouzadoux (eds.), Image et religion dans l'Antiquité grécoromaine. Actes du colloque de Rome, 11-13 décembre 2003, organisé par l'École française d'Athènes, l'ArScAn (UMR 7041 : CNRS, Paris I, Paris X), l'équipe ESPRI et l'ACI jeunes chercheurs ICAR, Napoli 2008.

ETIENNe 1966

R. Etienne, La vie quotidienne à Pompéi, Paris 1966.

FARAONe 1993

C. Faraone, "The Wheel, the Whip and other Implements of Torture: Erotic Magic in Pindar Pythian 4.213-19", The Classical Journal 89, 1 (1993), 1-19. 
FARAONe 1999

C. Faraone, Ancient Greek Love Magic, Cambridge Ma-London 1999.

GALlo 1988

A. Gallo, «Le pitture rappresentanti Arianna abbandonata in ambiente pompeiano", Rivista di Studi Pompeiani 2 (1988), 57-80.

GASPARri 1986

C. Gasparri, s. v. Dionysos, LIMC III 1, 1986, 420566.

GAZDA 2000

E. K. Gazda (ed.), The Villa of the Mysteries in Pompeii: Ancient Ritual, Modern Muse, Ann Arbor 2000.

Grieco 1979

G. Grieco, "La grande frise de la Villa des Mystères et l'initiation Dionysiaque», La Parola del Passato 34 (1979), 417-441.

GUARDUCCI 1993

M. Guarducci, "Dioniso e la cosiddetta Villa dei Misteri a Pompei», Atti della Accademia Nazionale dei Lincei 4 (1993), 521-533.

Harcourt-SMith 1929

C. Harcourt-Smith, "Whip-tops», Journal of Hellenic Studies 49 (1929), 217-219.

HeARnShaw 1999

V. Hearnshaw, "The Dionysiac Cycle in the Villa of the Mysteries. A Re-reading", Mediterranean Archaeology: Australian and New Zealand journal for the archaeology of the Mediterranean world 12 (1999), 43-50.

Herrero de Jáuregui et al. 2011

M. Herrero de Jáuregui, A. I. Jiménez San Cristóbal, E. R. Luján Martínez, R. M. Hernández, M. A. Santamaría Alvarez, S. Torallas Tovar (eds.), Tracing Orpheus: Studies of Orphic Fragments in Honour of Alberto Bernabé, Berlin-New York 2011.

Hirst 1937

G. Hirst, "Note on Vergil Aeneid VII. 376-384», The Classical Quarterly 31 (1937), 65-66.

ILES JOHNSTON 1990

S. Iles Johnston, Hekate Soteira. A Study of Hekate's Roles in the Chaldean Oracles and Related Literature, Atlanta 1990.

ILES JOHNSTON 1995

S. Iles Johnston, "The Song of the Iynx: Magic and Rhetoric in Pythian 4", Transactions and Proceedings of the American Philological Association 125 (1995), 177-206.
ILES JOHNSTON 1999

S. Iles Johnston, Restless Dead. Encounters between the Living and the Dead in Ancient Greece, Berkeley-Los Angeles-London 1999.

JАССотTет 2003

A.-F. Jaccottet, Choisir Dionysos : les associations dionysiaques ou la face cachée du dionysisme, I e II, Zürich 2003.

JATTA 1906

M. Jatta, "Vasi dipinti dell'Italia meridionale», Monumenti antichi. Pubblicati per cura della Reale Accademia dei Lincei 16 (1906), 493-532.

KASTNER 1995

M.-O. Kastner, "L'enfant et les jeux dans les documents d'époque romaine», Bulletin de l'association Guillaume Budé 1 (1995), 85-100.

LAWLER 1927

L. B. Lawler, "The Maenads: a contribution to the study of the dance in ancient Greece», Memoirs of the American Academy in Rome 6 (1927), 69-112.

LEHMANN 1962

K. Lehmann, "Ignorance and search in the Villa of the Mysteries», Journal of Roman Studies 52 (1962), 62-68.

\section{LesCHi 1935/36}

L. Leschi, "Mosaïque à scènes Dionysiaques de Djemila-Cuicul (Algerie)», Monuments et mémoires. Publiés par l'Académie des inscriptions et belles-lettres (Fondation Piot) 35 (1935/36), 1-34.

LEVANIOUK 2007

O. A. Levaniouk, "The toys of Dionysos", Harvard Studies in Classical Philology 103 (2007), 165-202.

LING 1991

R. Ling, Roman Painting, Cambridge 1991.

LORENZ 2008

K. Lorenz, Bilder machen Räume: Mythenbilder in pompeianischen Häusern, Berlin 2008.

LORENZ 2016

K. Lorenz, Mythological Images and their Interpretation. Iconology, Semiotics and Image Studies in Ancient Art History, Cambridge 2016.

MAIURI 1931

A. Maiuri, La Villa dei Misteri, Roma 1931.

MaCCHIORO 1929

V. Macchioro, Zagreus. Studi sull'orfismo, Bari 1929.

Marsoner 1989/1990

A. Marsoner, «La struttura ad anello nel grande fregio della Villa dei Misteri», Annali dell'Istituto italiano per gli studi storici 11 (1989/1990), 27-54. 


\section{Marianna Scapini, The winged figure in the "Villa dei Misteri" fresco and the spinning top in ancient rituals}

Mastrocinque 2014

A. Mastrocinque, Bona Dea and the Cults of Roman Women, Stuttgart 2014.

Matz 1963

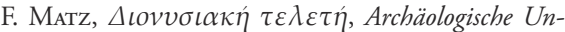
tersuchungen zum Dionysoskult in hellenistischer und römischer Zeit, Mainz-Wiesbaden 1963.

MAC Góráin 2013

F. Mac Góráin, «Virgil’s Bacchus and the Roman Republic», in D. Nelis, J. Farrell (eds.), Augustan Poetry and the Roman Republic, Oxford 2013, 124-145.

Merkelbach 2003

R. Merkelbach, I Misteri di Dioniso, Genova 2003.

Minto 1925

A. Minto, "Saturnia etrusca e romana. Le recenti scoperte archeologiche», in Monumenti antichi pubblicati per cura della Reale Accademia dei Lincei, 30, 3 (1925), 585-710.

NiLSSON 1957

M. P. Nilsson, The Dionysiac Mysteries of the Hellenistic and Roman Age, Lund 1957.

PICARD 1954

G.-Ch. Picard, «La Villa Item (Pompéi) devra-t-elle être rebaptisée : Villa sans mystères'?", Revue Archéologique (1954), 96-102.

Pfuhl 1923

E. Pfuhl, Malerei und Zeichnung der Griechen, III, München 1923

RiCCIARDELLI 2000

G. Ricciardelli, "Mito e performance nelle associazioni Dionisiache», in M. Tortorelli Ghidini, A. Storchi Marino, A. Visconti (eds.), Tra Orfeo e Pitagora. Origini e incontri di culture nell'antichità, Atti dei seminari napoletani 1996-1998, Napoli 2000, 265-283.

RICHARDSON 1979

E. Richardson, "The Story of Ariadne in Italy», Studies in Classical Art and Archaeology: A Tribute to Peter Heinrich von Blanckenhagen, New York 1979, 189-195.

Rizzo 1918

G. E. Rizzo, "Dionysos Mystes. Contributi esegetici alla rappresentazione dei misteri orfici», Memorie della Reale Accademia Arch. di Napoli 3 (1918), 39-101.

RoBERTSON 1993

N. Robertson, "Athens' Festival of the New Wine», Harvard Studies in Classical Philology 95 (1993), $197-$ 250.
RoDenWALdT 1932

G. Rodenwaldt, «Spinnende Hetären», Archäologischer Anzeiger 47 (1932), 7-21.

RostovtZeFf 1928

M. Rostovtzeff, Mystic Italy, New York 1928.

SAURON 1998

G. Sauron, La grande fresque de la Villa des Mystères à Pompei, Paris 1998.

SCAPINI 2012/2013

M. Scapini, "Iconographic aspects of the winged demon of the "Villa dei Misteri"", PHASIS. Greek and Roman Studies 15-16 (2012/2013), 481-492.

SCAPINI 2015

M. Scapini, "Whipping in myth, ritual and magic practice: a case of convergence», in E. Suárez, M. Blanco, E. Chronopoulou (eds.), Los papiros mágicos griegos: entre lo sublime y lo cotidiano, Madrid 2015, 93-109.

SCAPINI 2016 a

M. Scapini, Le stanze di Dioniso. Contenuti rituali e committenti delle scene dionisiache domestiche tra Roma e Pompei, Madrid 2016.

SCAPINI 2016b

M. Scapini, "The Symbolism of the Hornet in the Greek World", in P. Johnston, A. Mastrocinque, S. Papaioannou (eds), The Role of Animals in ancient Myth and Religion, Proceedings of the Symposium Grumentinum "The Role of Animals in ancient Myth and Religion" (Grumento Nova, Italy, 5-7 June 2013), Cambridge 2016, 431-445..

SCAPINi 2016 (forthcoming)

M. Scapini, "Augustus and Dionysus' triumph: a nonexistent paradox", Acta Antiqua Academiae Scientiarum Hungaricae, forthcoming.

SCARPI 2002

P. Scarpi, Le Religioni dei Misteri, vol. I, Milano 2002.

SCHEFOLd 1952

K. Schefold, Pompejanische Malerei. Sinn und Ideengeschichte, Bâle 1952.

SCHEFOLD 1972

K. Schefold, La peinture pompéienne. Essai sur l'évolution de sa signification, Bruxelles 1972.

SEAFORD 2006

R. A. S. Seaford, Dionysos: Gods and Heroes of the Ancient World, New York 2006.

Sfameni Gasparro 1986

G. Sfameni Gasparro, Misteri e culti mistici di Demetra, Roma 1986. 
Simon 1961

E. Simon, "Zum Fries der Mysterienvilla bei Pompeij", Jahrbuch des Deutschen Archäologischen Instituts 76 (1961), 111-172.

Tortorelli GHidini 2000

M. Tortorelli Ghidini, «I giocattoli di Dioniso tra mito e rituale», in M. Tortorelli Ghidini, A. Storchi Marino, A. Visconti (eds.), Tra Orfeo e Pitagora, origini e incontri di culture nell'antichità. Atti dei seminari napoletani 1996-1998, Napoli 2000, 255-263.

Toynbee 1929

J. Toynbee, "The villa Item and a Bride's Ordeal», Journal of Roman Studies 19 (1929), 77-87.

Trendall, G. Schneider-Herrmann 1975

A. D. Trendall, G. Schneider-Herrmann, «Eros with a whipping-top on an Apulian pelike», Bulletin Antieke Beschaving 50 (1975), 267-270.

TurCAN 1969

R. Turcan, «La démone ailée de la Villa Item», in J. Bibauw (ed.), Hommages à Marcel Renard, I-III, Bruxelles 1969, 586-609.

TurCan 1982

R. Turcan, "Pour en finir avec la femme fouettée», Revue Archéologique (1982), 291-302.

TurCAN 1992

R. Turcan, «L'élaboration des mystères dionysiaques à l'époque hellénistique et romaine : de l'orgiasme à l'initiation ", in A. Moreau (ed.), L'Initiation. Actes du colloque international de Montpellier, 11-14 avril 1991. I. Les rites d'adolescence et les mystères, Montpellier 1992, 215-233.

TurCan 2003

R. Turcan, Liturgies de l'initiation bacchique à l'époque romaine (Liber) : documentation littéraire, inscrite et figurée, Paris 2003.
TurCan 2004

$\mathrm{R}$. Turcan, Les cultes orientaux dans le monde romain, Paris 2004 (I ed. 1989).

Veyne, Lissarrague, Frontisi-Ducroux 2003 P. Veyne, F. Lissarrague, F. Frontisi-Ducroux, I misteri del gineceo, Roma- Bari 2003.

Villanueva Puig 2009

M.-Ch. Villanueva Puig, Ménades : recherches sur la genèse iconographique du thiase féminin de Dionysus des origines à la fin de la période archä̈que, Paris 2009.

Von DuHn 1957

M. Von Duhn, "Die Gleichnisse in den Allectoszenen des 7. Buches von Vergils Aeneis", Gymnasium 64 (1957), 59-83.

WYLER 2008

S. Wyler, "Des images dionysiaques aux limites du religieux : le cubiculum 4 de la villa des Mystères», in Estienne, Jaillard, Lubtchansky, Pouzadoux 2008, 449-459.

WyLER $2008^{1}$

S. Wyler, "Le dionysisme dans la villa : initiation familiale ou contre-modèle social ?», in P. Galland, C. Lévy (eds.), La villa et l'univers familial dans l'antiquité et à la Renaissance, Paris 2008, 61-78.

WYLER 2004

S. Wyler, "Dionysos domesticus' : les motifs dionysiaques dans les maisons pompéiennes et romaines (II ${ }^{\mathrm{e}}$ s. av.- ${ }^{\mathrm{Ier}}$ s. ap. J.-C.)", Mélanges d'Archéologie et d'Histoire de l'École Française de Rome. Antiquité 116 (2004), 933-951.

ZuNTZ 1963

G. Zuntz, "On the Dionysiac Fresco in the Villa dei Misteri at Pompei", Proceedings of the British Academy 49 (1963), 177-201. 